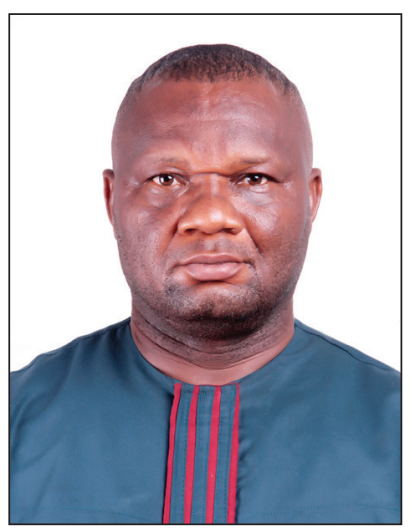

Nwocha Matthew Enya,

PhD, Faculty of Law,

Ebonyi State University,

Abakaliki, Nigeria

e-mail:nwochaenyaeni@gmail.com

\title{
INDUSTRIAL LAW AND THE PRODUCTIVE CAPACITY OF LABOUR IN NIGERIA
}

This Paper has discussed the various employment laws in the country and the inherent defects in them that have impacted negatively on staff productivity. The Paper came against the background of the low productive output of the Nigerian worker that has adversely affected the growth of the national economy and created room for fraud and corruption in the public service as well as the private sector. The Paper has found that aside of defective labour laws, the mentality of Nigerian courts to labour disputes, the negative attitude of Nigerian workers and poor work ethics, and the poor conditions of service in the labour sector all contribute to low output and productivity. Therefore, the Paper has suggested ways that these negative trends can be reversed among them, the amendment of the extant industrial lawes and improvement of the working conditions of the Nigerian employee.

Keywords: National economy; development; employee; labour law; productivity; industrial relationship; labour disputes; adjudication.

Нвоча Маттгев Эния, доктор философии, юридический факультет, Эбонийский государственный университет, Нигерия, г. Абакалики.

e-mail: nwochaenyaeni@gmail.com

Трудовое законодательство и производительность труда в Нигерии

В статье рассмотрены различные законодательные акты, касающиеся проблем занятости в Нигерии, а также присущие им недостатки, которые отрицательно сказываюттся на производительности труда работников. Определены способы устранения этих негативных тенденций путем внесения поправок в законы, касающиеся производственной сферы, а также улучшения условий труда.

Ключевые слова: национальная экономика; развитие; работник; трудовое право; производительность; производственные отношения; трудовые споры; судебное разбирательство.

Introduction. Industrial or labour law is the law that regulates the relationship between an employer and employee including the contract of employment, terms 
of contract, conditions of service, schedule of work, safety in work, and reward of service. For Abbott et al, the duties of an employee are governed by the terms of his contract and in the absence of any express or implied terms, his duties are determined by common law ${ }^{1}$. The same is applicable to the employer. Industrial law in Nigeria has been quite a controversial one. There are a number of reasons why this is the case. Among them is the fact that there is a multiplicity of legislations that constitute Nigerian industrial or labour law. Each of these legislations are designed to serve various ends with the overall objective of securing a peaceful and productive labour environment. However, some of these legislations actually duplicate and, in some cases, contradict certain provisions contained in the other thereby creating loopholes for the employer to exploit against the worker. At other times, the implementation of these legislations work hardship on the staff thereby frustrating his hopes of a rewarding and self-fulfilling career, well deserved disengagement benefits and a life of comfort after retirement. The courts have not helped matters by standing on the side of employers of labour, most of the time. The consequence of all of these situations is the low morale among Nigerian workers and an even lower productive output. This, as expected, has severe negative consequences on the growth of the Nigerian economy. The Paper therefore seeks to evaluate labour laws in the country with a view to finding how staff welfare and productivity may be enhanced for a sustainable growth of the economy.

Industrial Law in Nigeria. There are a number of legislations that regulate industrial services, labour welfare and labour relations in Nigeria. These legislations include the Constitution of Nigeria, 1999; the Labour Act; Employees' Compensation Act; Trade Unions Act; Trade Disputes Act; Factories Act; Pension Reform Act; and the National Industrial Court Act ${ }^{2}$. Section 4 (2) of the Constitution of Nigeria vests the power to legislate on labour matters exclusively on the federal government ${ }^{3}$. According to Uvieghara, the sources of Nigerian labour law include the constitution, legislation and common law ${ }^{4}$. Basically, the Labour Act contains general provisions as to protection of wages, contracts of employment and terms and conditions of employment. A principal issue of concern to the Labour Act is the protection of employees' wages. To this end, the Act provides in section 1 for the manner in which such wages may be paid. Consequently, the wages of a worker shall in all contracts be made payable in legal tender and not otherwise. Additionally, no employer shall impose in any contract for the employment of any worker any terms as to the place at which, or in the manner in which, or the person with whom any wages paid to the worker are to be expended. Any contract between an employer and an employee containing any such terms shall be illegal, null and void ${ }^{5}$. Again, wages

\footnotetext{
${ }^{1}$ K. Abbott, N. Pendlebury, K. Wardman (2013) Business Law, 9th ed. UK: CENGAGE Learning. Pg. 520.

2 See generally J. Olakanmi (2012) Labour Law Handbook, 3rd ed. Abuja; Lawlords Publications.

${ }^{3}$ This is detailed under items 10, 34, and 44 of Part I of the Second Schedule to the Constitution particularly item 34 .

${ }^{4}$ E.E. Uvieghara (2001) Labour Law in Nigeria. Lagos: Malthouse Press Ltd. Pg. 2.

${ }^{5}$ Section 2 of the Labour Act, 1971.
} 
shall not be paid to a worker in premises used for the sale of intoxicating liquor or for the retail sale of goods, unless, in the case of retail sale of goods, a worker has his employment in the premises ${ }^{1}$.

With regard to contracts of employment, an employer is duty bound to provide to the employee not later than three months of the employment written particulars of the terms of his employment. Such particulars shall include the name of the employer or group of employers; the name and address of the worker and the place and date of his engagement; the nature of the employment; if the contract is for a fixed term, the date when the contract expires; the appropriate period of notice to be given by the party wishing to terminate the contract; the rates of wages and method of calculation thereof and the manner and periodicity of payment of wages; any terms and conditions particularly as it relates to hours of work, holidays and holiday pay, or incapacity for work due to sickness or injury as well as sick pay; and any special conditions of the contract ${ }^{2}$.

As it concerns terms and conditions of employment, the Labour Act makes regulations as to the hours of work and overtime. It provides that normal hours of work in any undertaking shall be those fixed by mutual agreement; collective bargaining; or by an industrial wages board especially in the absence of a collective bargaining machinery. Furthermore, the hours which a worker is required to work in excess of the normal hours fixed through any of the above methods constitutes paid overtime ${ }^{3}$.

The Labour Act is a welcome one owing to its equitable balance of responsibilities and reward between the worker and his or her employer. However, the Act has been criticized over concerns with the employment of children and young persons. Section 59 (1) of the Act allows the use of a child's labour by a member of his family on agricultural or domestic work. This has created a window for the unconscionable exploitation of child labour for commercial agriculture ${ }^{4}$ and the inhuman treatment of children who are domestic servants, a tendency that is widespread in Nigeria. Furthermore, section 59 (3) of the Act allows the employment of a person under the age of fourteen on a daily wage and on a day to day basis. There is no doubt that this is a way of promoting child labour. A community reading of sections 59 (1) and 91 discloses that the Labour Act again does not define who a family member is. It only adopts the definition contained in the Workmen's Compensation Act that has itself been repealed by the Employees' Compensation Act, 2010. This being the case, reliance on finding the meaning of a family member can validly be placed on African customary practice or African customary law which recognizes family members to include widely extended family relatives or blood relations and not just parents or

\footnotetext{
${ }^{1}$ Section 3 of the Labour Act, 1971.

${ }^{2}$ Section 7 (1) of the Labour Act, 1971.

${ }^{3}$ Section 13 of the Labour Act, 1971.

${ }^{4}$ This is even true especially against the background that section 91 of the Act defines agricultural undertaking as meaning any undertaking in which a worker is employed under a contract of employment for the purpose of agriculture, fisheries, horticulture, silviculture, the tending of domestic animals and poultry or the collection of the produce of any plants or trees that does not include any such undertaking in which only members of the same family are employed.
} 
siblings of the same parents. Going by this approach, the Labour Act has inadvertently created room for exploitation of child labour or that of young persons by distant relatives who have neither compassion nor the interest at heart of the child or young person that is the potential victim. The weakness of the Labour Act in relation to the potential exploitation of children and young persons is compounded by the provision in section 64 to the effect that even where an employer violates the few safeguards made for the child and young person under the Act he would only, if found guilty by the court, pay a paltry fine of one hundred naira ${ }^{1}$. The specific provision of section 64 of the Act is that:

Any person who employs a young person in contravention of sections 59 to 62 of this Act or any regulations made under section 63 of this Act, the proprietor, owner and manager of any undertaking in which a young person is so employed and any parent or guardian of a young person who permits the young person to be so employed shall be guilty of an offence and on conviction shall be liable to a fine not exceeding $\mathbf{N 1 0 0 .}$

Also among the labour laws in Nigeria is the Employee's Compensation Act, 2010. The stated objectives of the Act are to provide for an open and fair system of guaranteed and adequate compensation for all employees or their dependents for any death, injury, disease or disability arising out of or in the course of employment, provide rehabilitation to employees with work-related disabilities; establish and maintain a solvent compensation fund managed in the interest of employees and employers; provide for fair and adequate assessments for employers; provide an appeal procedure that is simple, fair and accessible with minimal delays; and combine efforts and resources of relevant stakeholders for the prevention of workplace disabilities, including the enforcement of occupational safety and health standards ${ }^{2}$. These objectives set the tone for the principal provisions of the Act.

Section 56 of the Act sets up the Employees' Compensation Fund into which shall be credited all money, funds or contributions by employers for adequate compensation to employees or their dependants for any death, injury, disability or disease arising out of or in the course of employment. Again, the fund shall consist of a take-off grant from the federal government; contributions payable by employers into the fund; fees and assessments charged or made pursuant to the Act or any regulations made thereunder; proceeds of investments of the fund; gifts and grants from any national or international organizations; and any other money that may accrue to the fund from any other source ${ }^{3}$. The fund is managed by the National Social Insurance Trust Fund Management Board established under the Nigeria Social Insurance Trust Fund Act, 1993. In order for a worker to be entitled for compensation, the Act requires that in every case of injury or disabling occupational disease to an employee in a workplace, the employee or in the case of death, the dependant,

\footnotetext{
${ }^{1}$ The current exchange rate is five hundred naira to one US dollar, though it fluctuates.

${ }^{2}$ Section 1 of the Employees' Compensation Act. By section 2, the Act applies to all employers and employees in the public and private sectors in Nigeria.

${ }^{3}$ Section 56 (2) of the Employees' Compensation Act, 2010.
} 
shall within fourteen days of the occurrence or receipt of the information of the occurrence, notify the employer by giving him information of the disease or injury to a manager, supervisor, first-aid attendant agent in charge of the work where the injury occurred or other appropriate representative of the employer. Such information shall include the name of the employee, the time and place of the occurrence; and the nature and cause of the disease or injury if known ${ }^{1}$. By section 5 of the Act, the employer is obligated to report to the National Social Insurance Trust Fund Management Board and the Office of the National Council for Occupational Safety and Health within seven days of its occurrence every injury to an employee that is, or is claimed to be, one arising out of and in the course of employment. Section 7 of the Act provides that any employee, whether or not in a work place, who suffers any disabling injury arising out of or in the course of employment shall be entitled to payment of compensation. And no employee shall agree with his employer to waive or to forego any benefit or right to compensation to which the employee or the dependants are or may become entitled ${ }^{2}$. Any such agreement shall be void and unenforceable. Part IV of the Employees' Compensation Act details the rate, scale and quantum of compensation payable to the worker relative to the degree of loss or injury suffered by him ranging from permanent partial disability, permanent total disability, to death.

As it pertains to compensation of the Nigeria worker for work-related injuries or loss, the Employees Compensation Act is commendably far-reaching and comprehensive. But the Act has a number of shortcomings which include the enormous powers invested on the National Social Insurance Trust Fund Management Board by sections 31 and 32 of the Act that places the management of the funds, the determination of rights and entitlements, and the scale of compensation almost at the discretion of the Board. There is a huge problem here because aside of the human operators in the Board being predisposed to exploiting these powers to attain personal ends, these unbridled powers can give rise to stiff administrative bottlenecks that could only make the Nigeria worker vulnerable and even helpless. Second, failure by the employer to make a report of death; injury or any other disease encountered by the employee to the Board might dispossess the employee of the benefits of compensation under the $\mathrm{Act}^{3}$. It is unjust that an employee can suffer from the deliberate acts of negligence of his employer. This is more so given that the Act applies to both public and private firms. Private firms in Nigeria have little or no supervision with regard to the way they hire, remunerate or fire their employees or the discharge of obligations owed to them. Under this atmosphere, the stakes are high that the fruits of his labour under the Act may in the end elude the employee. Third, the scale of compensation though adequate still crashes on the hard rock of the harsh economic climate that has emasculated the Nigerian worker since the late 1980s which has increased in intensity until the present deep economic recession of 2016 and 2017.

\footnotetext{
${ }^{1}$ Section 4 of the Employees' Compensation Act, 2010.

${ }^{2}$ Section 13 (1) of the Employees' Compensation Act, 2010.

${ }^{3}$ Sections 4 (4) and 5 (5) of the Employees' Compensation Act 2010.
} 
With very low wages worsened by the abysmal value of the naira, survival for the Nigerian worker is a matter of daily struggle. His situation and that of his dependants is clearly worse when he suffers any loss of life or permanent disability and gets to be paid only a fraction of his monthly wages.

There is also amongst labour law in Nigeria, the Trade Unions Act. This is a federal legislation that regulates the formation, registration and organization of trade unions, federations of trade unions and the central labour organization. It legitimizes the formation of employees and employers into appropriate unisons for the pursuit of their shared interests. The Act has assisted in a tremendous way in reducing the tension and mutual distrust between employers and employees and also enhanced the process of collective bargaining. However, the Act has come down too heavily on unregistered trade unions. Such a union cannot operate or carry out any activity as such. And that is also the case where a registered union ceases to be registered ${ }^{1}$. Moreso, sections 3 and 4 of the Act gives the Minister of Employment, Labour and Productivity the absolute discretion to register a trade union or to deny it registration. Where registration is refused, workers may be exposed to exploitation, especially with the lack of opportunity for collective bargaining.

Again, there is the Factories Act, 1987, which regulates the registration of factories and other associated matters ${ }^{2}$. The Act makes safety guarantees for factory workers and a wider spectrum of workers and professionals against occupational hazards. The Act imposes penalties for breach of its provisions. Part II of the Act makes provisions for a healthy environment within the factory including its cleanliness, over-crowding, ventilation, lighting, drainage, and sanitary conveniences. Part III of the Act makes general provisions for safety of workers and machinery including prime movers; transmission machinery; powered machinery; unfenced machinery; construction and maintenance of fencing; construction and disposal of new machinery; vessels containing dangerous liquids; self-acting machines, training and supervision of inexperienced workers; hoists and lifts; chains, ropes and lifting tackle; cranes and other lifting machines; safe means of access where dangerous fumes are likely to be present; precautions with respect to explosive or inflammable dust, gas, vapour or substance; steam boilers; steam receivers and steam containers; air receivers; prevention of fire and safety provisions in case of fire outbreak. Parts IV and $\mathrm{V}$ of the Act provide for the general welfare of workers including supply of drinking water; washing facilities; accommodation or clothing; first aid; removal of dust or fumes; prohibition of meals in dangerous places; protective clothing and appliances; and protection of eyes in certain processes.

As it pertains to the health, safety and welfare of workers, the Factories Act is indeed comprehensive and far-reaching. The major problem with the Act though, is that the punishment it prescribes for contraventions of its provisions are grossly

\footnotetext{
${ }^{1}$ Section 2 of the Trade Unions Act, 1973.

${ }^{2}$ This is by coverage similar to the Indian Factories Act of 1948 which according to Bose was enacted principally to protect workers employed in factories against industrial and occupational hazards and to regulate the conditions of work in manufacturing establishments. See generally D.C. Bose (2008) Business Law. New Delhi: PHI Learning Private Limited, p. 393.
} 
inadequate and ineffectual. As illustration, operating a factory without having registered it attracts a fine not exceeding two thousand naira under section 3 (4) of the Act and one hundred naira each day the offence continues after the initial conviction. Section 20 (2) of the Act imposes a fine not exceeding five thousand naira on any person who manufactures, assembles, sells or lets on hire or who as an agent of the manufacturer, assembler, seller or hirer causes or procures to be sold or let on hire for use in a factory in Nigeria any machinery that does not comply with quality standards set by the Act. Section 50 (4) imposes a fine not exceeding one thousand naira for unlawfully disclosing or publishing the result of a medical test conducted on a worker. Section 51 (4) imposes a fine not exceeding one thousand naira on any employer or occupier who fails to report an accident occurring in the factory while obstructing an inspector of factories under section 65 (5) of the Act attracts a fine not exceeding one thousand naira. Under section 70 of the Act, the general penalty for contravening the provisions of the Act is a fine not exceeding five hundred naira and one hundred naira for any other day the contravention continues after the initial conviction. And in the case of death or injury, section 71 provides that:

If any person is killed or dies or suffers any bodily injury, in consequence of the occupier or owner of a factory having contravened any provision of the Act or of any regulation or order made thereunder, the occupier or owner of the factory shall, without prejudice to any other penalty, be liable to a fine not exceeding N5,000 or to imprisonment for a term not exceeding two years, or to both such fine and imprisonment, and the whole or any part of the fine may be applied for the benefit of the injured person or his family or otherwise as the court may order ${ }^{1}$.

All of these illustrations underscore the inadequacy of punishment attaching to violations of such a well thought-out legislation. The result is that the legislation is nothing more than a paper tiger which factory owners can afford to ignore or treat with disdain. And in the end, it is the Nigerian worker that bears the brunt of the insecure, unhealthy and dangerous environment that we find in most factories in the country.

Another significant labour law in Nigeria is the Trade Disputes Act. This Act sets the tone and procedure for settling trade disputes, including apprehension of trade dispute by the Minister of Labour and Productivity; appointment of conciliator; reference of dispute to arbitration tribunal if conciliation fails; issue of tribunal's awards and procedure thereon; reference of dispute to the National Industrial Court if tribunals award is objected to; and prohibition of lock-outs and strikes before issue of award of National Industrial Court ${ }^{2}$. In spite of its prohibition of grant of general wage increase by employers of labour or even by a tribunal or

\footnotetext{
${ }^{1}$ The penalties are as contained in sections 3 (4), 20 (2) (50 (4), 51 (4) 65 (5), and 70 already discussed. Note again that the current exchange rate, though prone to fluctuation, is five hundred naira to one US dollar. At this rate the fines prescribed by the Act are extremely nominal and the options of imprisonment though too lenient are never applied by Nigerian Judges who are only too conscious of the need to decongest Nigeria's over-crowded prisons.

${ }^{2}$ Sections 5, 8, 9, 13, 14, and 18 respectively of the Trade Disputes Act, 2006.
} 
court of which the Act has been severely criticized, the Trade Disputes Act has great and effective potentials for stability in the labour sector.

There is also the Pension Reform Act, 2004. The Act applies to workers in public and private employment in Nigeria and is aimed at bringing a comprehensive disengagement benefit to the doorsteps of Nigerian employees. It establishes a comprehensive pension scheme for payment of retirement benefits of workers. Where the scheme applies, both the employer and employee contribute equal and mutual percentages of the employee's monthly wage to the retirement fund for the benefit of the employee ${ }^{1}$. And the fund is administered by a Pension Fund Administrator appointed under the law while the pension scheme is regulated and supervised by the National Pension Commission established under section 14 of the Pension Reform Act. In addition, employers of labour can elect to bear the full burden of the total contributions to the pension scheme provided that such contribution shall not be more than fifteen per cent of each employee's monthly wage ${ }^{2}$. Employers of labour are also mandated under the Act to maintain a life insurance policy in favour of the employee for a minimum of three times the annual total emolument of the employee ${ }^{3}$. There is no doubt that the Pension Reform Act is a labour friendly legislation but its implementation has been bedeviled by fraud, corruption, mismanagement and administrative bottlenecks. All of these negative tendencies debar the Nigerian worker from reaping the full benefits of the Act, aside of the fact that certain classes of workers are not covered by the Act as for example workers in any private establishment having less than five employees ${ }^{4}$.

On adjudication of labour disputes, there is the National Industrial Court Act, 2006, which creates the National Industrial Court as a superior court of record ${ }^{5}$. Section 7 of the Act empowers the National Industrial Court to have and exercise exclusive jurisdiction in civil causes and matters relating to labour, including trade unions and industrial relations; environment and conditions of work, health, safety and welfare of labour; granting of any order to restrain any person or body from taking part in any strike, lock-out or any industrial action or any conduct in contemplation or in furtherance of a strike, lock-out or any industrial action; and the determination of any question as to the interpretation of any collective agreement, any award made by an arbitral tribunal in respect of labour dispute or an organizational dispute; the terms of settlement of any labour dispute or organizational dispute as may be recorded in any memorandum of settlement, any trade union constitution, and any award or judgment of the court. Notwithstanding,

\footnotetext{
${ }^{1}$ By section 9 (1) of the Pension Reform Act, the contribution is as follows: in the case of public servants, a minimum of seven and half percent by both the employer and employee; in case of the military, a minimum of twelve and half percent by both the employer and employee each; in other cases, a minimum of seven and half percent by both the employer and employee (including the private sector).
}

${ }^{2}$ Section 9 (2) of the Pension Reform Act, 2004.

${ }^{3}$ Section 9 (3) of the Pension Reform Act, 2004.

${ }^{4}$ Section 1 (2) (b) of the Pension Reform Act, 2004.

${ }^{5}$ Section 1 of the National Industrial Court Act, 2006. 
and without prejudice to the above powers of the court, the 1999 Constitution of Nigeria (Third Alteration) Act, $2010^{1}$, extended comprehensively the powers of the National Industrial Court. While consolidating the powers conferred on the court by the National Industrial Court Act, the constitution, as amended, extended the court's jurisdiction to several other subjects including but not limited to civil causes and matters relating to, connected with or arising from the Factories Act, Trade Disputes Act, Trade Unions Act, Labour Act, Employees' Compensation Act, or any other Act or law pertaining to labour, employment, industrial relations and work place; child labour, child abuse, human trafficking or any other matter connected therewith; application or interpretation of international labour standards; and disputes arising from payment or non-payment of salaries, wages, pensions, gratuities, allowances, benefits and any other entitlement of any employee, worker, political or public office holder, judicial officer or any civil or public servant in any part of the federation and matters incidental thereto. In terms of the establishment, constitution and jurisdiction of the National Industrial court, there is great hope and expectation that it can and will enforce the welfare of the Nigerian worker. But this expectation is only to be tested by what the court will do in fact after a reasonable period of its operation.

Constraints to Staff Productivity. The path to the maximization of the productive capacity of Nigerian workers is long, windy and tortuous. There are many factors that account for this situation, ranging from ambiguous and defective legislations; the attitude of the courts who are more inclined to interpreting labour disputes wearing the spectacles of employers of labour; the pre-disposition of the average Nigerian employee to his work; to the poor conditions of service which is the lot of the dominant class of Nigerian workers. The labour laws in Nigeria work in complementarity with each other to secure a better working condition and work environment for the Nigerian worker. However, there are a number of defects and inadequacies in the laws that need to be addressed if these objectives are to be attained for enhanced productivity. The Labour Act $^{2}$ defines a child as a young person under the age of twelve years while the Employees Compensation $\mathrm{Act}^{3}$ defines a child as any person not more than twenty one years old. These discrepancies in determining the age of eligible employees also affects their recruitment, job specification, conditions and terms of service, and even disengagement and pension rights. To illustrate this, section 20 (1) of the Trade Disputes Act stipulates that a person under the age of twenty one shall not be capable of being an official of a trade union. This and other discriminatory legislation are unfair especially given that such class of persons are eligible to be recruited as employees under cognate labour laws such as the Labour Act ${ }^{4}$.

There are also problems with sections 12 and 30 of the Employees' Compensation Act. In section 12, victims of loss or injuries can only be availed of compensation

\footnotetext{
1 Act No. 3.

2 Section 91 of the Labour Act, 1971.

3 Section 73 of the Employees' Compensation Act, 2010.

${ }^{4}$ Section 59 of the Labour Act, 1971.
} 
under the Act in lien of any other right of action whether statutory or in common law, and only if such injury or loss occurred in the course of employment. There are some unresolved issues relating to this provision. Foremost is that if compensation under the Act is in lieu of remedies under any other statute or common law, there is no provision for what happens where victims seek those remedies and fail or are frustrated from or in the course of seeking such statutory or common law remedies. This is a very important issue which the law needs to address given the overbearing influence brought upon the Nigerian judiciary by the government and large corporations who are the chief employers of labour in the country. Second, it is rather unfair that an employee who has served his employer faithfully cannot be availed of the benefits of the Act simply because he incurred a permanent total or permanent partial disability outside the course of his employment. Under section 30 of the Act, the Nigeria Social Insurance Trust Fund Management Board charged with the duty to implement the Act and to manage and dispense the employees' compensation fund are authorized to make rules for the reconsideration of benefits payable under the Act. The problem, however, is that without an objective guide as to the nature and degree of rules that this Board can make in this regard, a window would have been inadvertently opened for crushing red-tapism and needless manipulation by some self-seeking members of the Board.

With regard to the Trade Unions Act, sections 9 and 50 remain highly contentions. By section 9 of the Act, any trade union refused registration by the Registrar of trade unions appointed by the Government or whose registration has been cancelled by the Registrar stands dissolved. There is no doubt that this provision of the law exposes the organized labour to government manipulation and ultimately impacts negatively on their conditions of service. Again, under section 50 of the Act, any person who commits any offence under the Act is liable to a fine of fifty naira and, by section 49, providing false information to the Registrar attracts a fine of two hundred naira. This is in a country where the current exchange rate of the naira is approximately five hundred to one US dollar. This impacts negatively on the good and positive provisions of the Act in that anybody or union that violates them would almost go scot-free. This grossly inadequate fine has the potential of entrenching a culture of impunity, and there might be deeper consequences of false information provided to the registrar of trade unions. Similarly, under the Factories Act, the fine for offences under the Act range from one hundred naira to two thousand naira and five thousand naira in extreme cases where there is loss of life. ${ }^{1}$ These fines constitute the weak link of the Act and require to be remedied by an upward review. And this is more so if the employee would offer his best services and pay due diligence and commitment to his duties. Furthermore, the provision in section 9 (5) of the Pension Reform Act, 2004, that any employee to whom the Act applies may in addition to the total contributions being made by him and his employer, make voluntary contributions to his retirement savings account is highly inappropriate as corrupt employees who are well placed or positioned can cash in on it to hide away

1 Sections 3 (4), 70, 71 and 72 of the Factories Act, 1987. 
moneys which they have stolen from their establishments or any other public office.

Again, judicial interpretation of employment laws and intervention in disputes has made the Nigerian employee over the decades to become increasingly crestfallen and even jittery. And the end result is a decreasing zeal and commitment to duty on the part of the average Nigerian worker. An illustration of this trend is the courts' uncritical mindset that a willing employee cannot be imposed on an unwilling employer. The courts have entrenched this policy assisted by the doctrine of judicial precedent such that no matter how unfair, unjust, humiliating or predative the dismissal of an employee may be no court is willing to order a re-instatement. In Kazeem Osisanya v. Afribank, ${ }^{1}$ the Supreme Court of Nigeria stated the position thus:

It has long been firmly established in several decided authorities of the court below and this court that a court cannot impose or foist on an unwilling employer, his or its employee... In a master and servant relationship, a dismissal of the employee by the employer, cannot be declared null and void and of no effect whatsoever. The employee's remedy is in damages where the termination of the appointment or dismissal is held to be wrongful.

The court went further to hold that an employer has a common law right to dismiss his employee without notice on grounds of misconduct or willful disobedience.

In spite of this blanket position, the courts have shown a tendency to distinguish between an employment with statutory flavour otherwise referred to as statutory appointment and the others based on contract of service. In Duduoye v. Nigeria Gas Company $L t d^{2}$, the supreme court after holding that the termination of a contract of service even if unlawful brings to an end the relationship of master and servant since the law is trite that an employee even though willing and able cannot be imposed on an unwilling employer, went on to hold that where parties to a contract mutually agree that the condition for termination is the giving of notice or payment of equivalent salary in lien of notice, the only valid way to discharge a party from this obligation is the payment of equivalent salary for the period of the notice. The question remains as to what happens even when the court finds that such termination is invalid or unlawful. The answer to this query appears to be supplied by another Supreme Court decision in Shell Petroleum Development Co. Ltd v. Olarewaju ${ }^{3}$ where the court in declining re-instatement held that the remedy for wrongful dismissal is in damages and that the measure of damages is prima facie the amount plaintiff would have earned had the employment continued according to the contract of employment, subject to the deduction in respect of amount accruing from any other employment which the plaintiff in minimizing damages either obtained or should reasonably have obtained. It would appear that the position will not change even where the employment is based on statute for the court in Dudusola's case after holding that where employment is regulated by statute, the employer is bound to

\footnotetext{
1 Supra; Chukwumah v. Shell Petroleum Development Co. Nigeria Ltd (1993) 5SCNJI; Olarewaju v. Afribank Nigeria PLC (2001) 7NSCQR 493.

2 (2013) 53. 3NSCQR 785.

3 (2008) 36 NSCQR 1187.
} 
comply with the conditions of service, otherwise any action taken to bring to an end the employment would be declared null and void and any other act based therein would also be void, still proceeded to hold that the law will not impose a willing employee on a unwilling employer.

The pre-disposition of the courts to take the side of the employers in declining re-instatement in cases of wrongful termination of appointment or dismissal is a huge discouragement to workers and a setback to staff productivity. It makes workers nervous and unwilling to offer committed service while officialdom becomes the order of the day. Such attitude of the courts, as observed earlier, is quite uncritical and unhelpful. It has not taken adequate consideration of the nature of public service and private employment in Nigeria. As it pertains to private employment, that is to say employment in the private sector of the economy or in private firms, organizations and institutions, the rule may be germane that you cannot impose a willing employee on an unwilling employer. Even at this, the calculation of the quantum of damages payable upon dismissal ought to take into account a number of factors including the employee's financial condition, his chances of getting another suitable employment and the time it will take him to do so, the length of time he has served in the employment, and the quantum of creativity and expertise he has invested to improve the business of his employer.

In the case of employment in the public service, the courts do not seem to mind the fact that the public service of Nigeria is a huge one. A federal employee can work in any of the thirty six states and the federal capital territory of Abuja all divided up into the North, West and Eastern parts of the country. A reinstated civil or public servant in the North can be transferred to the East or West and there would be no immediate person in his new place of assignment that would hold any grudge against him as to become an unwilling employer. There is also a multiplicity of ministries and parastatals where workers who are wrongfully dismissed can be re-instated and re-posted or re-assigned responsibilities. The same applies to States of the federation and even local government areas. The willing servant against an unwilling master doctrine is therefore by no means a sacrosanct one as the courts would make it appear. Its direct import is the creation of uncertainty that lowers employee productive output.

Also affecting staff productivity in the country is the mentality of the average Nigerian worker who has the mental fixation that he must get wealthy through the job he does. It does not matter to him the nature of skill and competence he has taken to the job nor his level or rank. The pre-disposition to acquire easy wealth has made most Nigerian workers to cut corners and look only after themselves at the expense of their lawful duties. This results in loss of focus, negligence of duty, corruption and fraud such that a huge well-funded public parastatal or firm that should make profit to grow the economy is eaten away by human terminates over a few years and becomes a drain pipe on the national economy rather than grow it. In the last decade, almost all public service providers such as NITEL, NEPA, Nigeria Airways, Nigeria Railway Corporation, Nigeria Ports Authority have been 
grounded because of fraud perpetrated by the employees and their political mentors. This resulted in the privatization of most of these public enterprises whose current operators have become regrettably engrossed with profit maximization rather than provision of services on a fair profit. ${ }^{1}$ The Nigerian economy today is in permanent recession partly because employees both in public and private sectors have been unhelpful and less than productive owing to their negative pre-dispositions.

There is also the ubiquitous incidence of absentee or unavailable workers popularly referred to in the country as ghost workers. Nigerian politicians and their top public servants have perfected the craft of injecting into the public payroll lists of fictitious names as civil servants and collect their wages on monthly basis to enrich themselves whereas these people are non-existent. This contributes in hiking the huge wage bill that the government has to pay while receiving no service from such payment thereby draining public resources, crippling the national economy, and leaving little finances at government disposal for capital expenditure, provision of infrastructure and other essential services.

In fairness, attention needs be paid to the poor conditions of service which the Nigerian worker has to live with. Apart from employees in the oil and banking industries, the vast majority of Nigerian workers wallow in poverty occasional by very low wages, spiraling inflation and high cost of basic services, medication, food, housing, education and other necessaries. This is in a country where politicians fall over themselves in looting the national treasury. Certain aspects of the Nigerian labour law have not been helpful to the employee. Even in the face of low wages, section 19 of the Trade Disputes Act prohibits any employer, on pain of three years imprisonment for an individual and in the case of a body corporate a fine of twenty five thousand naira, to grant a general or percentage wage increase to any group of employees without the approval of the Minister of Labour and Productivity. The Minister represents government's interest and on that account wages will continue to be low at the pleasure of government. Even more intriguing is the provision of section 18 of the Trade Disputes Act which bars workers from engaging in lock-outs and strikes unless and until the National Industrial Court issues an award to them. The combined effect of these sections of the law in addition to other unfavourable legislation already pointed out in the discussion only complicates the hardship faced by the Nigerian worker. The result is the very low morale among workers with its multiplier effect of low output and productivity. This situation has also given rise to corruption and fraud where workers resort to self-help to improve their living conditions and secure a good life after retirement. It is not surprising, therefore, that the huge public service employees and their counterparts in the private sector do not contribute enough to the development of the national economy.

Recommendations for Improved Labour Productivity. To reactivate and boost staff productivity, concerted efforts in this regard should be made on different fronts.

\footnotetext{
${ }^{1}$ See generally M.E. Nwocha (2010) «An Appraisal of Economic Liberalization and Sustainable Development in Nigeria» in Abuja Journal of Public and International Law, Vol. 1 No. 1, August 2010, pp. 42-56.
} 
First, there must be a review of those labour laws that demoralize workers by making the labour sector uncertain, insecure and unrewarding. There must be a standardization of the age limit for a child and a young person in the Labour Act, Employees' Compensation Act, Trade Disputes Act and other relevant legislations. The current discrepancies in the age limits for children and young persons in these mentioned laws have implications for the contributions these class of persons make to national development and the rewards which they reap from it. In addition, section 12 of the Employees' Compensation Act should be amended to allow victims of injuries or loss the opportunity of reaping the benefits of the Act where they are not satisfied with and reject any award made pursuant to any statute or at common law or where efforts in this regard are frustrated owing to any set of reasons. Furthermore, victims of permanent total or permanent partial disability should be able to have some compensation even where they have suffered these losses outside their course of employment. This is mainly because a person who has tuned and focused his entire life to the service of his employer with commitment and dedication should not be abandoned by his employer simply because he has had his misfortune outside the course of his employment. Again, section 30 of the Employees' Compensation Act should be amended to create an objective guideline under which the Nigeria Social Insurance Trust Fund Management Board can make rules for reconsideration of benefits payable under the Act rather than leaving it entirely to their discretion as is presently the case. The use of their absolute discretion has resulted in arbitrariness and unfair and inequitable application of the Act.

Similarly, section 9 of the Trade Unions Act should be amended to remove the power of the Registrar of trade unions from unilaterally dissolving any trade union by merely cancelling its registration. Such powers should be transferred to the National Industrial Court. Again, section 9(5) of the Pension Reform Act that allows employees to make additional voluntary contributions to their retirement savings account should be amended to place a ceiling on the amount of contributions specific classes of employees can make. This is to avoid a situation where high level employees begin to steal money from their employers and hide same in their retirement savings account. Furthermore, the punishment sections of the Trade Unions Act, Factories Act and other relevant labour laws should be upgraded to impose punishments that reflect current realities and value of the naira and enough to deter violators of labour laws made to benefit the employee.

Second, the Nigerian judiciary must shake off its mental fixation that willing and able employees cannot be imposed on an unwilling employer as exemplified in Supreme Court decisions in Ziideh v. Rivers State Civil Service Commission ${ }^{1}$, Osisanya v. Afribank ${ }^{2}$ and sundry other kindred cases. They must consider the circumstances of the employment in line with our earlier discussion in this Paper and order re-instatement or re-engagement in appropriate cases $^{3}$. Third, the Nigerian employee must

1 (2007) 29 NSCQR 701.

2 (2007) 29 NSCQR 282.

3 The basic remedies for unfair dismissal according to MacIntyre include reinstatement, re-engagement, 
wean himself of the propensity to create illegitimate wealth from his employment. He must change his overall attitude and disposition to work by imbibing decent, productive and result-oriented work ethics. The incidence of ghost workers must be eliminated by creating accurate and reliable statistics and data of visible and existing workforce. Fourth, it is time that the Nigerian government and employers of labour generally took the welfare and working conditions of employees seriously. Nigerian workers ought to be well paid and motivated to deliver their best services. Wages, retirement benefits and other allowances and emoluments of all classes of workers must be competitive and compare with global trends.

Fifth, the National Industrial Court must be pro-active and alive to its responsibilities. It must be flexible enough to interpret labour disputes expansively particularly where it concerns provisions that are designed for the benefit of the workforce. The court should expedite action on labour disputes brought before it and not allow itself become a dumping ground for labour disputes where government would prevent organized labour from embarking on strike and lock-outs under section 18 of the Trade Disputes Act only to abandon negotiations with labour and dump the dispute in the court with the aim to frustrate the demands of labour. In addition, the court should be bold to speak to power in the interest of national development. At the same time, the court should discountenance unreasonable and unrealistic demands of over-zealous and implacable labour leaders and create a balance necessary to grow the national economy. When all of these recommendations have been put into action, the labour laws would be strengthened and staff productivity would witness a remarkable boost.

Conclusion. Industrial laws in Nigeria are designed to create an effective and efficient labour force that can make meaningful contribution to the development of the national economy. These laws include the Constitution of the Federal Republic of Nigeria, Labour Act, Employees' Compensation Act, Trade Unions Act, Trade Disputes Act, Factories Act, Pension Reform Act, and the National Industrial Court Act. These laws have additionally been designed to foster stability in the Nigerian labour market and to avert industrial disharmony. However, a close study of the laws as done in this Paper has revealed that there are certain defects inherent in them that need to be corrected if the objectives of enacting them would be actualized in a sustainable way. And propositions for these amendments have been made. The poor and negative attitude of the Nigerian employee to work has been analyzed as part of the factors that impact on his productivity including, and in addition to, his poor conditions of service. And finally, recommendations have been made in order to strengthen Nigerian employment laws and promote staff productivity in the country.

and compensation. See E. MacIntyre (2008) Business Law. Harlow: Pearson Education Limited, p. 155 . 


\section{References:}

1. Abbott, K., Pendlebury, N., Wardman, K. (2013). Business Law, th $^{\text {th }}$ ed. UK: CENGAGE Learning.

2. Bose, D.C. (2008). Business Law. New Delhi: PHI Learning Private Limited.

3. Constitution of the Federal Republic of Nigeria, 1999.

4. Employees' Compensation Act, 2010.

5. Factories Act, 1987.

6. Labour Act, 1971.

7. MacIntyre E. (2008). Business Law. Harlow: Pearson Education Limited.

8. National Industrial Court Act, 2006.

9. Nwocha M.E. (2010). «An Appraisal of Economic Liberalization and Sustainable Development in Nigeria» in: Abuja Journal of Public and International Law, Vol. 1, No. 1.

10. Olakanmi, J. (2012). Labour Law Handbook, $3^{\text {rd }}$ ed. Abuja: Lawlords Publications.

11. Pension Reform Act, 2004.

12. Trade Disputes Act, 2006.

13. Trade Unions Act, 1973.

14. Uvieghara, E.E. (2001). Labour Law in Nigeria. Lagos: Malthouse Press Ltd.

Нвоча Маттгев Енія, доктор філософії, юридичний факультет, Ебонійський державний університет, Нігерія, м. Абакалікі.

e-mail: nwochaenyaeni@gmail.com

\section{Трудове законодавство і продуктивність праці в Нігерії}

У статті розглянуто різноманітні законодавчі акти, що стосуються проблем зайнятості в Нігерії, а також властиві їм недоліки, які негативно позначаються на продуктивності праці прачівників. Зазначені чинники негативно впливають на начіональну економіку, створюють можливості для шахрайства та корупиї як у державному, так і в приватному секторах. Установлено, що недосконале трудове законодавство, неналежний рівень компетентності нігерійських судів при розгляді трудових спорів, негативне ставлення до них самих працівників, погані умови праці в промисловому секторі є причиною низької якості продукції і продуктивності праці. Запропоновано способи усунення цих негативних тендениій, зокрема шляхом унесення поправок до законодавчих актів щодо промисловості, а також поліпшення умов праці.

Ключові слова: національна економіка; розвиток; працівник; трудове право; продуктивність; виробничі відносини; трудові спори; судовий розгляд.

Надійшла до редколегї 24.04.2017 p. 